\title{
Corporate Capital of Domestic and Foreign Firms in Africa - An Empirical Review
}

\author{
${ }^{1}$ onwuka, Ifeanyi Onuka \& ${ }^{2}$ Nwafor, Michael Chukwunaekwu \\ ${ }^{1}$ Department of Accounting \& Finance, Godfrey Okoye University, Enugu State, Nigeria \\ ${ }^{2}$ Department of Accounting \& Finance, Godfrey Okoye University, Enugu State, Nigeria
}

\begin{abstract}
The study evaluated the existence and nature of systematic competition for corporate capital between local and foreign firms operating in major African economies. The study is motivated by the debate that foreign firms have easier access to corporate capital than domestic firms, and that the problem in the global financial market might push foreign firms to rely more on domestic financial markets for funds. To achieve the goal of this study, both microeconomic and macroeconomic data were sourced from diverse sources - including the World Bank's Global Development Indicators' database and the individual annual financial reports of firms. The data generated a total of 351 firms based in 11 African countries over a period 2009 to 2014. The results show that the average ratio of total liabilities to total assets is slightly higher among the listed foreign firms (at 48.8 percent) than among the listed domestic firms (47.9 percent), although the differences does not appear significant at conventional levels $(t$-statistic $=0.601$; prob. $>t=0.548)$. For the whole sample also, it is shown that foreign firms have higher long-term liabilities to total asset ratio than domestic firms, and that the difference is significant at 10 percent level. Whereas the average long-term debt ratio among foreign firms stands at 12.1 percent, for domestic firms, the level is 10.7 percent $(t$-statistic $=1.751 ;$ prob. $>t=0.080)$. In none of the four sub regions, though, does the difference in the long-term debts ratio significantly differ between domestic and foreign firms. Consistent with the statistical evidence, the descriptive results seem to suggest that the survey evidence reported by the World Bank that in Africa, foreign firms are more profitable, larger, more valued in terms of investments in fixed assets, and older than domestic firms is not true. However, as shown in this report, such differences, with the exception of asset tangibility and age, are not very significant at conventional levels. This suggests that the major source of competition for corporate finance in Africa may be on the extent of collateral value and the reputation that arises from firm age.
\end{abstract}

Keywords: Corporate Capital, Corporate Competition, Domestic Firms, Foreign Firms

\section{Introduction}

A very crucial policy issue among key economic managers in Africa is whether foreign firms' access to local financial markets increases the intensity of financial constraints faced by domestic firms in the region. While the weight of the issue has historically been suppressed by the fact that foreign firms, especially the multinational and transnational corporations have traditionally wider access to corporate finance, increasing financial pressure due to persistent financial crisis in most of the developed economies, has recently remotivated this debate. This is coupled with the available theoretical and statistical evidence that foreign firms have incentives to make use of the local financial markets in their host countries. Ironically in the event of scramble for local financial resources, foreign firms can be more competitive than local counterparts, because of their easy access to both the domestic and the international financial markets. The underlying assumption is that they are more attractive to lenders and investors because of their high financial flexibility, compliant with global standards for financial accounting, disclosure and corporate governance, superior performance, and higher collateral value. Foreign firms may therefore utilize their vantage position to out-compete other classes of firms in the host economies. This development has wider socioeconomic implications, including public concerns for the welfare of the local economy and that of key local economic agents. In Africa, particularly, these concerns are felt more and tend to focus on the need to protect and guarantee the growth of indigenous business enterprises. By implication, this issue influences virtually all aspects of corporate stakeholdership; and may have the tendency of exacerbating antagonism against foreign companies operating in the African region.

Incidentally, some past government policies, in most African economies, have been targeted at enhancing the competitiveness of local firms, especially as it relates to access to finance and control. Examples of such policies are the privatization, indigenization and general economic reforms. The privatization policy, initiated by respective governments in the late 1980s, had been targeted largely at repositioning the economies for global integration and development. On its part, the Indigenisation Policy, adopted in the region since the early 70s, was radically aimed at transferring businesses from foreign to indigenous control. According to Okafor (1983), for instance, the main intention of the indigenization policy was to ensure deeper involvement of Africans in the ownership and control of domestic enterprises without necessarily discouraging the inflow of 
foreign investments. It was equally alleged that some African governments adopted the policy to limit the level of foreign control in their respective economies (Ejiofor, 1981:15).

Despite the economic implications of this nationality debate, little research interests have so far been attracted thereto. Past corporate finance studies do not seem to have captured much of the contending issues bordering on the trends and implications of financing competition between foreign and local firms. This is so, despite the fact that a number of studies that examined the financing structures of firms in the region highlighted the disadvantaged positions of local firms (see for instance Ezeoha, 2011, 2008, Abor, 2006; and Booth et al.; 2001). It is therefore difficult to make any meaning projections as to how the drying-up of the traditional funding sources for multinational and foreign firms would impact on the competition for corporate funds in the African region. Without such empirical proof, it may be very difficult for policy makers to actually understand how developments in the international financial markets affect the funding patterns of the local corporations; and to enforce reasonable rules on how to ameliorate the negative impacts of financial competition on the operations of local economic agents. Most of the existing empirical studies that constitute the present platform for corporate governance/ownership/financing debates in Africa ironically are of Western origin. The foreignness of existing empirical evidence makes it difficult for African governments to formulate and effectively enforce policies that are capable of encouraging the free flows of foreign investments and capital while at the same time catering for the resource needs and growth of the indigenous corporate sector.

To close the above research gap, this study primarily strives to establish the existence and nature of systematic competition for corporate finance between local and foreign firms operating in major African economies. To achieve this, the study provides answers to the following questions: Are foreign firms relatively larger than domestic firms in Africa? Consistent with the Trade-Off Theory, does such size advantage give them greater access to the domestic capital markets? Do foreign firms enjoy some special reputation that, in accordance with the propositions of the agency theory, gives them more access to the domestic capital markets than domestic firms? Are foreign firms more profitable than domestic firms? In line with the proposition of the Pecking Order Theory, does higher profitability reduce their reliance on the domestic capital markets? Do foreign firms have higher collateral values than domestic firms? Consistent with both the Agency and Trade-off Theories, does such higher collateral value reduce or intensify their reliance on the domestic capital markets?

\section{Characteristics of Business Ownership In Africa}

Local firms in Africa generally share some basic features that tend to constrain their capacity to compete in the global markets for factor inputs. Available evidence on the legal statue of the firms, for instance, suggests that majority of firms do not have the limited liability status and so by their nature are not qualified to use variety of funding options. As shown in figure 2, for instance, less than 20 percent of business firms in most of the countries have attained the limited liability status. Similarly, in terms of size, in most of the African countries, up to 80 to 90 percent of the firms are classified as small and medium scale in Africa clustering around 80 percent and 90 percent (see figure 2). In fact, with the exception of Egypt, Morocco and Ethiopia, the percentage of large-scale enterprises to the total number of enterprises averages less than 15 percent in all the other countries. In Nigeria and South Africa, the level is just about 2.4 percent and 11.2 percent, respectively. This is as compared to the levels of 47.1 percent and 23.1 percent in Thailand and Brazil.

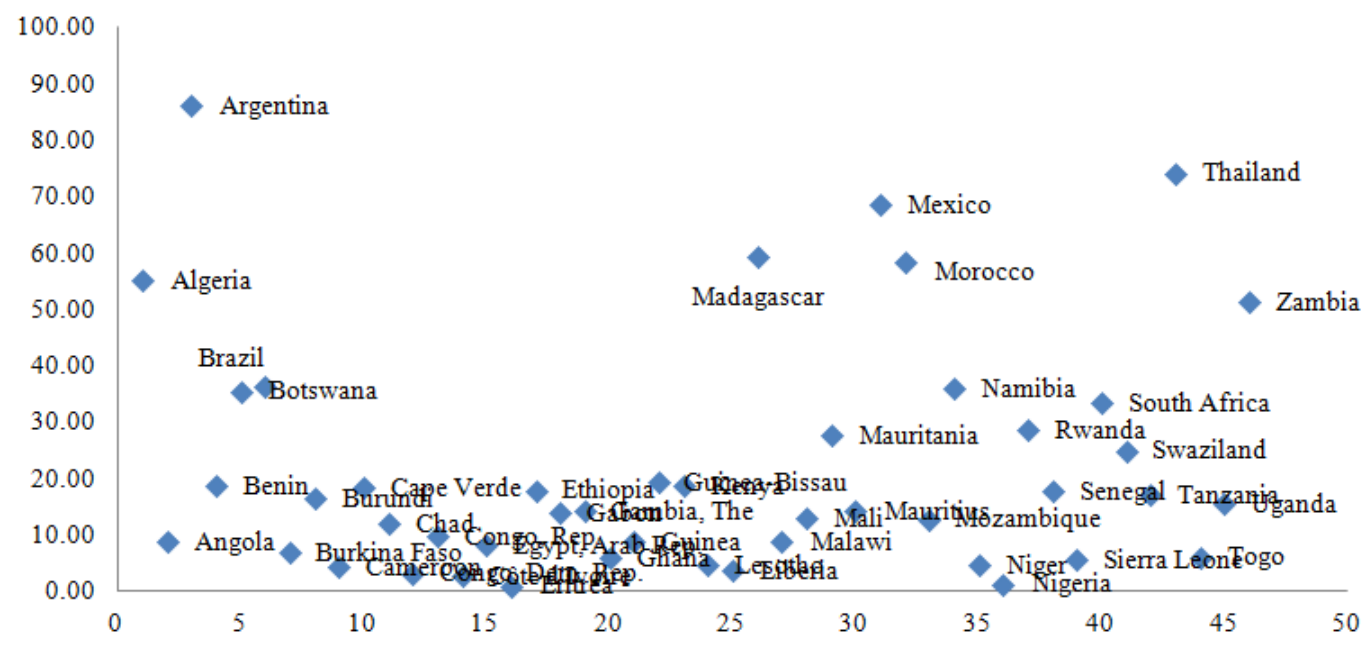

Figure 1: Percentage of Limited Liability Companies in the African Region Source: Computed, based on data from 2010 World Development Indicators 


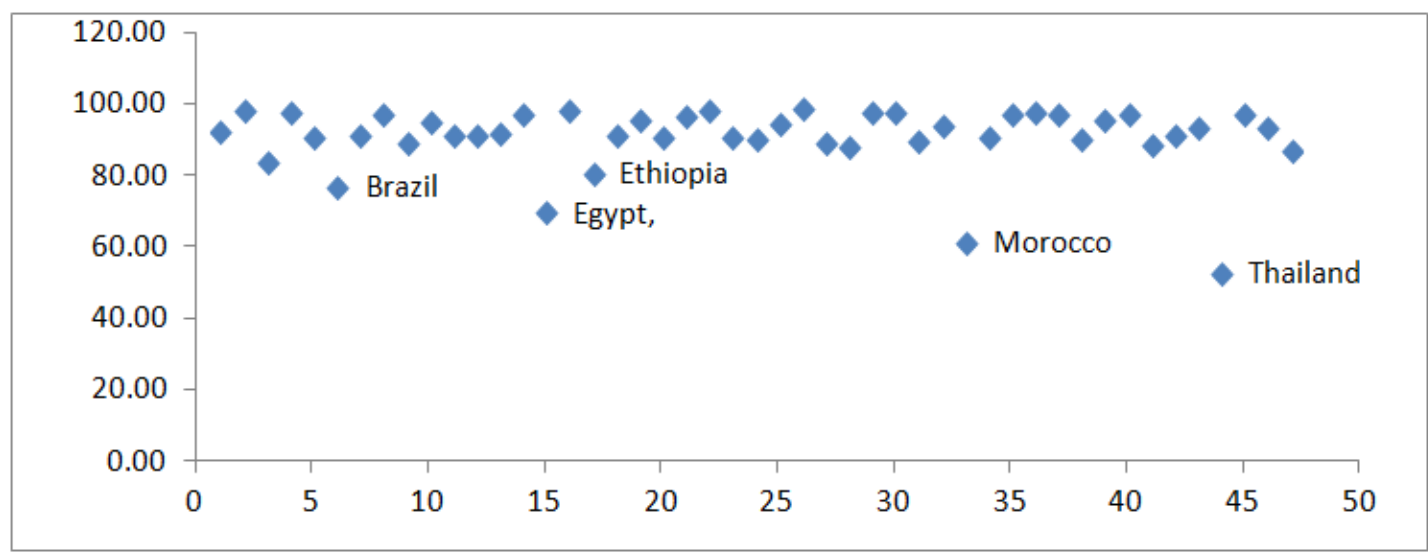

Figure 2: Percentage of Small and Medium Scale Firms to Total Number of Firms in the Region Source: Computed, based on data from 2015 World Development Indicators

In terms of ownership, available evidence also suggests that, up untill 1960s, business ownership in Africa was divided between a small group of minority of local Africans, a large group of local foreigners, foreign private business enterprises, and joint ventures between two or more of the above (Engberg-Pedersen et al., 1996:36). However, compare to the patterns in the pre-indigenisation and early-independence eras, the stakes of domestic agents in the ownership of businesses in the region seem to have significantly increased. As shown in figure 3, Gabon (54.7\%), Botswana (41.2\%), Swaziland (35.1\%), Madagascar (32.2\%) and Lesotho (25.4\%) occupy the top five positions among countries with the highest percentage of private foreign ownership of businesses in Africa. On the other side, Nigeria (98.9\%), Algeria (97.4\%), Sierra leone (96.7\%), Senegal $(95.4 \%)$ and Ghana $(94.6 \%)$ are the top five countries with the highest level of private domestic ownerships. There is feasible absence of government ownership in most of the countries, with only 9.4 percent and 2.7 percent recorded as the highest levels in Ethiopia and Gabon, repsectively.

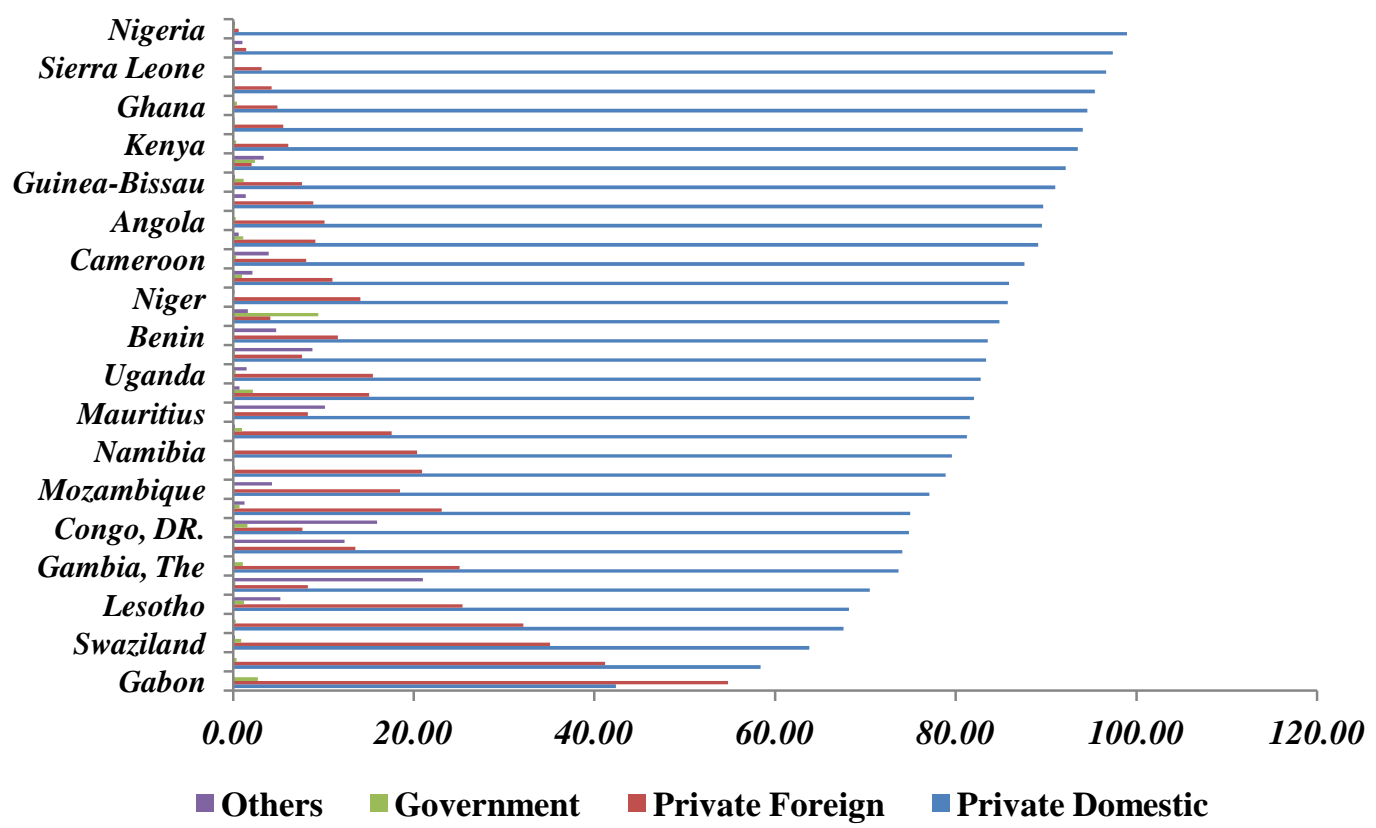

Figure 3: Patterns of Business Ownership in Africa

Source: Computed based on data from 2015 World Development Indicators

However, in terms of size and influence, foreign firms still occupy dominance space in the African corporate environment. Further evidence from a World Bank survey reveals that foreign firms are larger in terms of number of employees, older, and have more transparent accounting practice. For the sampled countries, on the average, 25.1 percent of the foreign firms have more than 100 persons in their employment, as against only 7.4 percent for domestic firms. In terms of age, the average age of foreign firms in the selected countries is 15.8, compared to 12.6 for the domestic firms. As much as 76.9 percent of the foreign firms subject their annual financial statements for external auditing, as against 51.8 percent in the case of domestic firms. The pattern is 
similar in most of the countries, including in Ghana, Egypt, Kenya, Malawi, Mauritius, Nigeria, Tanzania and Zambia. These factors, can combine to give a firm comparatively higher access to external finance. The implications of this skewedness in size and age, for instance, especially on firms' capacity to access the financial markets, have been well documented in capital structure literature (Titman and Wessels, 1988; Erickson and Trevino, 1994; Rajan and Zingales, 1995; Booth et al., 2001; Fama and French, 2002, Schoubben and van Hulle, 2004). On the impact of large firms having competitive advantage in the market for corporate finance, for instance, the argument has been that such firms have higher capacity to meet up with interest payments, and are more diversified than smaller firms (Pandey, 2004; Cardone-Riportella and Cazorla-Papis, 2001), enjoy higher degree of information disclosure (Fama and Jensen, 1983; Rajan and Zingales, 1995), and have higher collateral values and lesser bankruptcy risks (King, 1977).

\section{Corporate Financial Competition}

As articulated by Armstrong and Shimizu (2007), a firm with necessary competitive advantage is one that has more efficient production process capable of meeting the needs of its consumers. Such a firm is expected to have superior performance and better operational efficiency than its competitors. From the perspective of the resource-based theory advanced by Barney (1991), a competitive firm is one relatively more endowed in all assets, capabilities, organizational processes, firm attributes, information, knowledge, etc. In terms of access to finance, necessary internal and external characteristics that give a firm greater access to credit can constitute sources of competitive advantage for such firm in the credit market.

Some testable hypotheses demonstrating why and how capital structures differ across firms have featured prominently in the capital structure literature. Some of such hypotheses are that larger, older, and more profitable firms have greater access to finance than smaller, newer, and less profitable ones (United Nations, 1973; and Majumdar, 2010). A theoretical premise, for example, is that in developing countries, foreign firms ought to have greater access to the financial markets because they are bigger, better governed and more profitable. In the case of Africa, a United Nations Trade and Development (UNCTAD) Report on Foreign Direct Investments in Africa released in July 2009 indicated that the profitability of foreign companies in the Continent was consistently higher than in most other regions of the world, with the rate of return on FDI averaging about 29 percent since 1960. The report went further to show that between 1983 and 1997, the rate of return for United States of America (USA) companies in Africa was above 10 percent; whereas between 1989 and 1995, with the exclusion of Nigeria, the net income from British investments in the Sub-Saharan Africa increased by 60 percent.

As earlier indicated, a priori, the theoretical position is that foreign firms make use of the domestic financial markets to fund their operations, and by so doing impose some competitive threats in the markets. Hennart (2010) demonstrates that firms establishing a plant in a foreign country can expand without capital importation from home country by accessing both internal and external sources of finance from outside the country of the parent. Li et al. (2009) also hold that foreign firms may be interested in domestic loans due to preferential interest rates and/or for hedging purposes. Similarly, Harrison et al. (2004) demonstrate that although foreign investors might bring in scarce capital to ease host-country corporate financing obstacles, such benefits can easily be erased if incoming foreign investors borrow heavily from domestic banks - leading to a situation where multinational firms exacerbate financing constraints by crowding host-country firms out of domestic capital markets. This trend is aggravated because non-financial firms looking for external financial sources primarily use debt or bond financing rather than equity financing (Godwani and Shrikhande, 2001).

Huizinga et al. (2008), Harrison and Mcmillan (2003) and Feldstein (1994) provide some insights as to why foreign firms make extensive use of the domestic capital markets. Consistent with the agency theory, for instance, Huizinga et al. (2008) demonstrate that a multinational firm might encourage its subsidiaries to keep up with a certain level of debt that effectively help monitor its local managers and consequently prevent them from exacerbating bankruptcy possibilities faced by the firm. Such a policy focus can induce affiliates towards greater utilisation of the domestic capital markets, since in some cases; it could be cheaper due to low interest rates. For foreign firms with local incorporation status, the use of domestic debt can also be induced by taxrelated factors. Using the case of United States of America foreign affiliates, Feldstein (1994) found that USA foreign affiliates, for instance, largely access host-countries' financial markets basically for the purpose of taking advantage of tax benefits of debt financing and also as a hedge against foreign exchange risks.

An important question that arises from the above argument is whether the reliance of foreign firms on domestic capital market implies better financing competitiveness relative to the domestic firms. No doubt, the underlying assumption is that foreign firms are generally more attractive to lenders and investors than domestic firms. The general reasons offered in previous literature for this, include that foreign firms are more financially flexible (Aggarwal and Kyaw, 2008), more compliant with global standards for financial accounting, disclosure and corporate governance (Global Development Finance, 2007), more profitable, and have more access to more collateral (Harrison and Mcmillan, 2010). Specifically, Aggarwal and Kyaw (2008) demonstrate that the ability 
of Multi-National Corporations (MNCs) to take advantage of differentials in tax and costs of external financing between home and host countries to minimise their overall tax burden and their overall cost of capital, places them on a better competitive position than domestic firms. This is possible because the level of economic exposure can significantly bear on the decision to use more of domestic debt or foreign currency denominated debts. Examples of such economic exposures that can constrain access to domestic borrowing are exposure to local currency revenues, variability in the host country exchange rate, and financial development in the host economy (Desai et al., 2008).

Exploring further the above premise, Goswani and Shrikhande (2001) explain that whereas firms with positive economic exposure make dominant use of Eurocurrency debt (rather than foreign debt and domestic debt); those with negative economic exposure use more of foreign currency debt financing. The implication of this on corporate financing is worsened by the inexplicable presence of bankruptcy costs, which makes domestic debt, foreign-currency debt, and Eurocurrency competitive financing alternatives.

Deliberate policy efforts by domestic government to attract foreign investments can also unduly favour foreign firms, especially with regard to access to local resources. In some instance, developing countries' governments promote and support foreign ownership of corporations based on expected positive externalities arising from the impression that such firms bring foreign capital and technological expertise (Harrison et al., 2004), enjoy systematic superior performance compared to their domestic counterparts (Bellak, 2004), and that there is a positive correlation between foreign direct investments and economic growth (Lee and Chang, 2009; Hermes and Lensink, 2003; and others).

Essentially, the influence of weak financial and legal institutions on the choice and implication of corporate finance is expected to be more for domestic firms than foreign firms. This is because the negative effects of economic exposures are likely not to undermine the competitiveness of foreign firms. In the case of Africa, factors such as type and quality of ownership, as well as the size of a firm determine how exposed the firm is to the structural deficiencies in the wider economy. In line with the positions of Ojah and Pillay (2009), and Denis and Mihov (2003), negative exposure on the part of foreign firms is minimised by the likelihood of higher credit ratings, which may give then a comparatively higher preference in the public debt markets. Evidence from the World Bank's Business Enterprises survey indicates that foreign firms enjoy higher credit rating, and so should have greater access to public debt markets than their domestic counterparts. In some cases, as identified by Ojah and Pillay (2009), information on firms' credit ratings is difficult to locate. Across firms and across countries, differentials in firms' financing structures are found to be influenced by firm-specific characteristics as well as by the constraints posed by countries' degree of financial development and their institutional environment (Claessens and Tzioumis, 2006).

\section{Methodology}

The broad objective of the study is to examine the existence and nature of systematic competition for corporate finance between local and foreign firms operating in major African economies. With this in mind, we first split the sampled firms according to the four regional groupings in Africa - Southern Africa, East Africa, West Africa and North Africa. The aim of this is to examine which region has the highest level of debt financing, as well as how the various firms characteristics such as profitability, size, age, risk and tangibility differ across the regions. Secondly we stratify the sample further into two categories - one for foreign firms and the other for domestic firms. The goal here is to provide answers as to whether foreign firms: are relatively larger than domestic firms in Africa; enjoy some special reputation that gives them more access to the domestic capital markets than domestic firms; are more profitable than domestic firms; have higher collateral values than domestic firms.

\section{The Research Data}

Annualized firm-level panel data and country-specific time series are used in the study to assess how firm-specific characteristics provide sources of financing competition in the markets for external corporate finance, especially among foreign and domestic firms in Africa. The data series cover the periods of 2009 to 2014 for firm-specific variables, and the data focus on listed non-financial firms. Due to the problem of data availability and the need to minimise the number of missing observations in our baseline estimation model, only a sample of listed firms in eleven stock exchanges in the Continent are used. The countries include: Botswana, Egypt, Ghana, Kenya, Mauritius, Morocco, Nigeria, South Africa, Uganda, Zambia, and Zimbabwe. ${ }^{1}$ In all, data from a total of 351 firms are used, with the number of South African firms accounting for about 50.4 percent of the total number of firms, followed by Nigerian listed firms with about 15.1 percent. A summary of the sample structure is presented in table 1 below.

\footnotetext{
${ }^{1}$ It is interesting to note that, in terms of size, to note that Egypt, Nigeria and South African accounted for about 94 percent of the total number of listed firms in the region's stock markets in 2008.

DOI: $10.9790 / 487 X-1902020110 \quad$ www.iosrjournals.org 5 |Page
}


Table 1: The Sample Structure

\begin{tabular}{|l|l|l|l|l|}
\hline Sub-Region & Country & No. of Firms & $\begin{array}{l}\text { \% of Total } \\
\text { No. of Firms }\end{array}$ & Total \\
\hline Southern Africa & & & & 210 \\
\hline & South Africa & 177 & 50.43 & \\
\hline & Botswana & 7 & 1.99 & \\
\hline & Mauritius & 3 & 0.85 & \\
\hline & Zimbabwe & 17 & 4.84 & \\
\hline Eastern Africa & & & & 28 \\
\hline & Kenya & 20 & 5.70 & \\
\hline & Uganda & 2 & 0.57 & \\
\hline & Zambia & 6 & 1.71 & \\
\hline Western Africa & & & & \\
\hline & Nigeria & 53 & 15.10 & 49 \\
\hline Northern Africa & Ghana & 11 & 3.13 & \\
\hline & Egypt & 35 & & 351 \\
\hline & Morocco & 14 & 3.99 & \\
\hline
\end{tabular}

Considering that corporate data on the performance and structure of African firms are not readily available in global databases such as CompuStat, data used in this study are carefully mined from diverse sources - including Thompson DataStream for South African listed firms; individual annual reports of the listed firms for the relevant years, in the case of Nigeria, and previous researchers such as Sources: Ezeoha (2008), Gwatidzo and Ojah (2009), Dawood et al. (2011).

\section{Variable Definitions}

Consistent with the definition used by Colombo (2001), we define a firm as foreign if the foreign share capital is greater than $10 \%$ and domestic otherwise. ${ }^{2}$ We define nationality as a dummy taking the binary digit 1 if foreign firm's shareholding in a locally incorporated firm is less than 10 percent and 0 if it is greater or equal to 10 percent. Profitability is defined in terms the ratio of operating income to total assets. Following Ferri and Jones (1979), Booth et al. (2001), Pandey (2004), and many others, we define size as the natural logarithm of turnover, rescaled by a multiple of 100. Also, following Loderer and Waelchli (2009) and Sakai et al. (2010), age is measured as one year plus number of years elapsed since the year of incorporation. Asset Tangibility is proxied as the ratio of book value of fixed assets to book value of total assets, while the definition of business risk takes after Lee and Kwok (1988) who measured it as the standard deviation of the first difference in earnings before interest and tax scaled by the mean value of the firm's total assets.

\section{Results}

Table 2 contains summary of comparative statistics for the panel 1999 to 2009 data, grouped according to domestic and foreign firms, as well as according to the four major sub-regional groupings in Africa. For the whole sample, the results show that the average ratio of total liabilities to total assets is about 48.4 percent. Comparatively, the ratio is slightly higher among the listed foreign firms (at 48.8 percent) than among the listed domestic firms (47.9 percent), although the difference does not appear significant at conventional levels ( $t$ statistic $=0.601$; prob. $>\mathrm{t}=0.548$ ). For the whole sample also, it is shown that foreign firms have higher longterm liabilities to total asset ratio than domestic firms, and that the difference is significant at 10 percent level. Whereas the average long-term debt ratio among foreign firms stands at 12.1 percent, for domestic firms, the level is 10.7 percent ( $\mathrm{t}$-statistic $=1.751$; prob. $>\mathrm{t}=0.080)$. In all the four sub regions, the difference in the longterm debt ratio did not significantly differ between domestic and foreign firms. Consistent with the statistical evidence provided, the descriptive results seem to suggest that the survey evidence reported by the World Bank that in Africa, foreign firms are more profitable, larger, more valued in terms of investments in fixed assets, and older than domestic firms is not entirely true. However, as shown in this report, such differences, with the exception of asset tangibility and age, are not very significant at conventional levels.

In terms of the levels of debt ratios across the four sub-regional groupings in the Continent, the results in table 2 reveal that firms listed in the West African sub-region has the highest average ratio of total liabilities to total assets (at 64.1 percent), followed by firms listed in the East African sub-region (at 50.7 percent), and

\footnotetext{
${ }^{2}$ In a survey of foreign firms in South Africa, Gelb (2002) classified foreignness in terms of firms with at least $10 \%$ foreign ownership, at least 10 employees currently in South Africa, some value-adding activity in South Africa, and first entry to South Africa after 1990
} 
those listed in the South African region (at 45.5 percent). North African firms are found to be the least leveraged, with an average debt ratio of 39.4 percent. That higher debt ratios for firms listed in Western and Eastern African sub-regions might suggest that access to equity finance is more difficult in these regions than in the Southern and Northern African sub-regions. Similarly, across the sub-regions domestic firms are shown, on average, to have higher debt ratio than foreign firms, although the difference is not very significant at any of the conventional levels ( $\mathrm{t}$-statistic $=-1.553$ ).

Essentially, it is only in the Western African and Southern African sub-regions that the difference in the leverage ratios of domestic and foreign firms is found to be statistically significant at conventional levels. The average leverage ratio for listed foreign firms in Southern Africa stands at 46.9 percent, compared to that of domestic firms at 44.5 percent $(\mathrm{t}$-statistic $=1.687$, prob. $>\mathrm{t}=0.092)$. Conversely, the ratio for listed domestic firms in West Africa is higher at 70.4 percent, compared to that of foreign firms which is 59.7 percent ( $\mathrm{t}$-statistic $=-3.273$, prob. $>\mathrm{t}=0.001)$.

Turning to the results of the independent variables, among the four sub-regions, Eastern African listed firms have highest average earnings ratio (profit ratio $=12.4$ percent), followed by Northern African listed firms who have average ratio of 11 percent. Southern African listed firms have an average earnings ratio of 9.3 percent, while Western African firms have the least ratio at just 7.5 percent. In terms of the difference in earnings ratios of domestic and foreign firms, the results reveal that statistically significant difference is noticeable only in the case of West African listed firms where the average ratio for foreign firms at 10.6 percent is statistically and significantly different from that of domestic firms at just 3.1 percent (with t-statistic $=4.891$; and prob. $>t=0.000)$. Similar trend, in terms of foreign firms being more profitable than domestic firms, is recorded in the cases of the other three sub-regional groupings, although the differences do not appear significant at conventional levels. In terms of size, statistically significant difference is recorded between domestic and foreign firms only among firms listed in Eastern and Western African sub-regions, with domestic firms being larger in the former whereas foreign firms are larger in the latter.

The levels of investments in fixed assets among listed firms in the four sub-regions rank in the following order: West African firms $=65.7$ percent, East African firms $=52.3$ percent; North Africa $=44.1$ percent; and lastly South Africa $=33.1$ percent. Of the sub-regions, the difference in the tangibility ratios of domestic and foreign firms is statistically significant only in South Africa ( $\mathrm{t}$-statistic $=3.854$; and prob. $>\mathrm{t}=$ 0.000 ), with foreign firms having higher ratio and North Africa ( $\mathrm{t}$-statistic $=-2.165$; and prob. $>\mathrm{t}=0.031$ ), with domestic firms having higher ratio. In terms of firm-age, measured as the 1 plus number of years from incorporation, the descriptive results show that listed foreign firms are statistically and significantly older than their domestic counterparts among firms listed in all the four sub-regional groupings. The mean levels of earnings volatility (our proxy for business risk) are similar in all the four sub-regions, with no significant difference found between foreign and domestic firms in each of the cases.

In all, table 3 reveals that profitability, size, business risk and nationality variables are each negatively correlated, while age and tangibility are each positively correlated with total debt ratio. With the exception of the pair of profitability and risk, the correlation coefficients between the firm-level independent variables are less than 0.10, suggesting that multicolinearity might not pose significant threat in the baseline model used for this study. Instead, multicolinearity is rather suspected between the country-level macroeconomic variables and the firm-level variables. This can be attributed to the structure of the data on country-level variables that are fixed across firms but differing across time.

A summary of the descriptive evidence highlighted in this section indicate that indeed in and within Africa, foreign firms are more profitable, larger, more valued in terms of investments in fixed assets, and older than domestic firms, although such differences are more feasible in terms of firm-age and asset tangibility. In line with the major objectives of this study, therefore, the key questions arising from such descriptive evidence are, among others, whether foreign firms being older have more access to the local capital markets than domestic firms; and whether the fact that foreign firms have higher collateral values reduces or intensifies their reliance on the domestic capital markets. Empirical answers to such questions are presented and discussed in the next section of this report. 
Table 2: Summary Statistics of the Estimation Variables and t-statistics on the Difference between Countries and between Firm-Nationality

\begin{tabular}{|c|c|c|c|c|c|c|c|c|}
\hline & & $\begin{array}{l}\text { Total } \\
\text { Debt }\end{array}$ & $\begin{array}{l}\text { Long-term } \\
\text { Debt }\end{array}$ & PROF & Size & RISK & TANG & AGE \\
\hline \multirow[t]{3}{*}{ Southern Africa } & $\mu$ & 0.455 & 0.008 & 0.093 & -0.026 & -0.001 & 0.331 & 1.444 \\
\hline & $\Sigma$ & 0.334 & 0.007 & 0.867 & 0.495 & 0.443 & 0.261 & 0.386 \\
\hline & NOB & 2222 & 2247 & 2246 & 2226 & 2257 & 2233 & 2305 \\
\hline \multicolumn{2}{|c|}{$\begin{array}{l}\text { t-Statistic } \\
\text { (Domestic Vs. Foreign) }\end{array}$} & $\begin{array}{l}1.687^{*} \\
(0.092)\end{array}$ & $\begin{array}{c}1.091 \\
(0.276)\end{array}$ & $\begin{array}{l}-0.567 \\
(0.571)\end{array}$ & $\begin{array}{l}-0.032 \\
(0.302)\end{array}$ & $\begin{array}{c}0.027 \\
(0.979)\end{array}$ & $\begin{array}{c}3.854 * * * \\
(0.000)\end{array}$ & $\begin{array}{l}7.266^{* * * *} \\
(0.000)\end{array}$ \\
\hline \multirow[t]{2}{*}{ Eastern Africa } & $\mu$ & 0.507 & 0.169 & 0.124 & 0.000 & -0.001 & 0.523 & 1.657 \\
\hline & $\Sigma$ & 0.345 & 0.011 & 0.194 & 0.278 & 0.152 & 0.339 & 0.275 \\
\hline \multicolumn{2}{|c|}{$\begin{array}{l}\text { t-Statistic } \\
\text { (Domestic Vs. Foreign) }\end{array}$} & $\begin{array}{l}296 \\
-0.731 \\
(0.466)\end{array}$ & $\begin{array}{l}297 \\
-0.386 \\
(0.700)\end{array}$ & $\begin{array}{l}298 \\
-0.054 \\
(0.957)\end{array}$ & $\begin{array}{l}298 \\
-1.614^{*} \\
(0.100)\end{array}$ & $\begin{array}{c}304 \\
-0.040 \\
(0.968)\end{array}$ & $\begin{array}{c}298 \\
0.270 \\
(0.788)\end{array}$ & $\begin{array}{c}298 \\
3.240^{* * *} \\
(0.001)\end{array}$ \\
\hline \multirow[t]{2}{*}{ Western Africa } & $\mu$ & 0.641 & 0.103 & 0.075 & 0.015 & -0.001 & 0.657 & 1.589 \\
\hline & $\Sigma$ & 0.408 & 0.018 & 0.195 & 0.349 & 0.136 & 4.371 & 0.193 \\
\hline \multicolumn{2}{|c|}{$\begin{array}{l}\text { t-Statistic NOB } \\
\text { (Domestic Vs. Foreign) }\end{array}$} & $\begin{array}{c}630 \\
-3.273^{* * *} \\
(0.001)\end{array}$ & $\begin{array}{c}636 \\
0.362 \\
(0.718)\end{array}$ & $\begin{array}{c}637 \\
4.891^{* * *} \\
(0.000)\end{array}$ & $\begin{array}{c}636 \\
4.128^{* * *} \\
(0.000)\end{array}$ & $\begin{array}{c}656 \\
-0.100 \\
(0.921)\end{array}$ & $\begin{array}{c}637 \\
0.990 \\
(0.323)\end{array}$ & $\begin{array}{c}704 \\
3.399 * * * \\
(0.001)\end{array}$ \\
\hline \multirow[t]{2}{*}{ Northern Africa } & $\mu$ & 0.394 & 0.104 & 0.11 & -0.269 & -0.002 & 0.441 & 1.501 \\
\hline & $\Sigma$ & 0.198 & 0.008 & 0.09 & 0.376 & 0.082 & 0.255 & 0.361 \\
\hline \multicolumn{2}{|c|}{$\begin{array}{l}\text { t-Statistic NOB } \\
\text { (Domestic Vs. Foreign) }\end{array}$} & $\begin{array}{c}487 \\
-0.159 \\
(0.874)\end{array}$ & $\begin{array}{c}487 \\
1.277 \\
(0.202)\end{array}$ & $\begin{array}{c}486 \\
0.925 \\
(0.355)\end{array}$ & $\begin{array}{c}487 \\
-0.323 \\
(0.746)\end{array}$ & $\begin{array}{c}487 \\
-0.450 \\
(0.653)\end{array}$ & $\begin{array}{c}487 \\
-2.165^{* *} \\
(0.031)\end{array}$ & $\begin{array}{c}539 \\
1.913^{*} \\
(0.056)\end{array}$ \\
\hline \multicolumn{9}{|l|}{ All Sample } \\
\hline \multirow[t]{3}{*}{ Domestic Firms } & $\mu$ & 0.479 & 0.107 & 0.093 & -0.05 & -0.001 & 0.357 & 1.434 \\
\hline & $\Sigma$ & 0.007 & 0.004 & 0.017 & 0.011 & 0.006 & 0.006 & 0.008 \\
\hline & NOB & 1798 & 1841 & 1823 & 1807 & 1842 & 1813 & 1911 \\
\hline \multirow[t]{3}{*}{ Foreign Firms } & $\mu$ & 0.488 & 0.121 & 0.096 & -0.049 & -0.001 & 0.478 & 1.556 \\
\hline & $\Sigma$ & 0.009 & 0.007 & 0.015 & 0.01 & 0.01 & 0.06 & 0.008 \\
\hline & NOB & 1837 & 1826 & 1844 & 1840 & 1862 & 1842 & 1945 \\
\hline \multirow[t]{3}{*}{ Overall } & $\mu$ & 0.484 & 0.114 & 0.095 & -0.049 & -0.001 & 0.418 & 1.495 \\
\hline & $\Sigma$ & 0.343 & 0.004 & 0.686 & 0.451 & 0.354 & 1.844 & 0.354 \\
\hline & NOB & 3635 & 3667 & 3667 & 3647 & 3704 & 3655 & 3856 \\
\hline \multicolumn{2}{|c|}{$\begin{array}{l}\text { t-Statistic } \\
\text { (Domestic Vs. Foreign) }\end{array}$} & $\begin{array}{c}0.601 \\
(0.548) \\
\end{array}$ & $\begin{array}{l}1.751^{*} \\
(0.080)\end{array}$ & $\begin{array}{c}0.664 \\
(0.507)\end{array}$ & $\begin{array}{c}0.073 \\
(0.942)\end{array}$ & $\begin{array}{l}-0.036 \\
(0.972)\end{array}$ & $\begin{array}{l}1.971 * * \\
(0.049)\end{array}$ & $\begin{array}{c}10.905^{* * * *} \\
(0.000)\end{array}$ \\
\hline
\end{tabular}

Note: $* * *$, and $* * *$ indicate that coefficients are significant at the 10 percent, 5 percent, and 1 percent levels, respectively.

Table 3: Pairwise Correlation Matrix

\begin{tabular}{|c|c|c|c|c|c|c|c|c|c|c|c|c|}
\hline & Debt & Debtt-1 & Profit & Tangibility & Size & Risk & Age & Nationality & RIR & BSD & REXR & $\mathrm{SMD}$ \\
\hline Debt & 1 & & & & & & & & & & & \\
\hline Debtt-1 & 0.031 & 1 & & & & & & & & & & \\
\hline Profit & -0.210 & -0.005 & 1 & & & & & & & & & \\
\hline Tangibility & 0.074 & 0.041 & -0.037 & 1 & & & & & & & & \\
\hline Size & 0.181 & 0.021 & 0.067 & 0.062 & 1 & & & & & & & \\
\hline Risk & -0.020 & 0.034 & 0.277 & -0.002 & 0.035 & 1 & & & & & & \\
\hline Age & -0.042 & 0.021 & 0.044 & 0.021 & 0.060 & 0.026 & 1 & & & & & \\
\hline Nationality & -0.014 & -0.013 & -0.003 & -0.033 & -0.001 & 0.001 & -0.173 & 1 & & & & \\
\hline RIR & -0.070 & 0.004 & 0.015 & 0.006 & -0.048 & -0.006 & 0.085 & -0.1186 & 1 & & & \\
\hline BSD & -0.099 & -0.122 & -0.028 & -0.059 & 0.022 & 0.078 & -0.187 & 0.212 & -0.133 & 1 & & \\
\hline REXR & -0.005 & -0.038 & -0.004 & 0.011 & -0.103 & 0.101 & 0.086 & -0.116 & 0.177 & -0.408 & 1 & \\
\hline SMD & -0.090 & -0.112 & -0.020 & -0.053 & 0.018 & 0.059 & -0.128 & 0.168 & 0.102 & 0.883 & -0.336 & 1 \\
\hline Inflation & -0.039 & 0.004 & 0.008 & 0.006 & -0.041 & 0.154 & 0.047 & -0.056 & 0.710 & -0.126 & 0.026 & -0.002 \\
\hline
\end{tabular}




\section{Conclusion And Recommendations}

The study sought to evaluate the existence and nature of systematic competition for corporate finance between local and foreign firms operating in major African economies. The need for the study arises from the general impression that foreign firms have easier access to finance than domestic firms, and that the current problems in the global financial markets might push the former to rely more on domestic financial markets for funds. Theories suggest that corporate nationality plays an important role in the financial behaviour of listed firms operating in Africa. In theory, foreign firms, for instance, may have more competitive and easier access to both the domestic and the international financial markets, mostly because they are high financial flexibility, compliant with global standards for financial accounting, disclosure and corporate governance, superior performance, and higher collateral value. The results show that the average ratio of total liabilities to total assets is slightly higher among the listed foreign firms than among the listed domestic firms, although the difference does not appear significant at conventional levels. For the whole sample also, it is shown that foreign firms have higher long-term liabilities to total asset ratio than domestic firms, and that the difference is significant at 10 percent level. In none of the four sub regions, though, does the difference in the long-term debt ratio significantly differ between domestic and foreign firms. Consistent with the statistical evidence provided in the earlier part of this report, the descriptive results seem to suggest that the survey evidence reported by the World Bank that in Africa, foreign firms are more profitable, larger, more valued in terms of investments in fixed assets, and older than domestic firms. However, as shown in this report, such differences, with the exception of asset tangibility and age, are not very significant at conventional levels. This suggests that the major source of competition for corporate finance in Africa may be on the extent of collateral value and the reputation that arises from firm age.

Across the sub-regions domestic firms are shown, on average, to have higher debt ratio than foreign firms, although the difference is not very significant at any of the conventional levels. Essentially, it is only in the Western African and Southern African sub-regions that the difference in the leverage ratios of domestic and foreign firms is found to be statistically significant at conventional levels.

A summary of the descriptive evidence highlighted in this section indicate that indeed in and within Africa, foreign firms are more profitable, larger, more valued in terms of investments in fixed assets, and older than domestic firms, although such differences are more feasible in terms of firm-age and asset tangibility. This implies that for domestic firms to reposition themselves to gain more access to the market for corporate finance, they need to focus more on building their collateral values, while at the same time leverage on the reputation and goodwill that comes with firm age. In line with the major objectives of this study, therefore, the key questions arising from such descriptive evidence are, among others, whether foreign firms being older have more access to the local capital markets than domestic firms; and whether the fact that foreign firms have higher collateral values reduces or intensifies their reliance on the domestic capital markets. This therefore calls for further empirical tests.

\section{References}

[1]. Abor, J. (2006), The effect of capital structure on profitability: an empirical analysis of listed firms in Ghana, The Journal of Risk Finance, 6(5): 136-145

[2]. Aggarwal, R. \& Kyaw, N. A. (2008) Internal capital networks as a source of MNC competitive advantage: Evidence from foreign subsidiary capital structure decisions, Research in International Business and Finance, 2(2):409-439

[3]. Armstrong, P. (2003). Status report on corporate governance reform in Africa. Johannesburg, South Africa: Pan-African Consultative Forum on Corporate Governance.

[4]. Armstrong, C. E. \& Shimizu, K. (2007) A review of approaches to empirical research on the resource-based view of the firm, Journal of Management, 33(6): 959-986

[5]. Barney, J. (1991), Firm resources and sustained competitive advantage. Journal of Management, 17(2): 99-120.

[6]. Bellak, C. (2004), How domestic and foreign firms differ and why does it matter?, Journal of Economic Survey, 18(4): 483-514

[7]. Booth, L.; Aivazian, V.; Demirguc-Kunt, A. \& Maksimovic, V. (2001), Capital structure in developing countries, The Journal of Finance, 56(1): 87-130.

[8]. Cardone-Riportella, C. \& Cazorla-Papis, L. (2001), New approaches to the analysis of the capital structure of SMEs: empirical evidence from Spanish firms, Department de Economia de la Empresa, Working Paper 01-10, Business Economics Series 03, January.

[9]. Colombo, E. (2001), Determinants of corporate capital structure: evidence from Hungarian firms, Applied Economics, 33(3):16891701

[10]. Claessens, S. \& Tzioumis, K. (2006), Measuring firms' access to finance, a paper presented at the conference access to finance: building inclusive financial systems, organized by the Brooking Institution and the World Bank in Washington, D.C., May 30-31.

[11]. Dawood, M. A.; Moustafa, E. L.; \& El-Hennawi, M. S. (2011), The determinants of capital structure in listed Egyptian corporations, Middle Eastern Finance and Economics, 9(1): 83-99

[12]. Denis, D. \& Mihov, V. (2003), The choice among bank debt, non-bank private debt, and public debt: evidence from new corporate borrowings, Journal of Financial Economics, 70(2): 3-28.

[13]. Desai, M. A.; Foley, C. F.; \& Forbes, K. J. (2008), Financial constraints and growth: multinational and local firm responses to currency depreciations, Review of Financial Studies, 21 (6): 2857-2888.

[14]. Erickson, S. M. \& Trevino, R. (1994). A pecking order approach to leasing: the airline industry case. Journal of Financial \& Strategic Decisions, 7(3): 71-81. 
[15]. Ezeoha, A. E. (2008), Firm size and corporate financial leverage choice in a developing economy: evidence from Nigeria, Journal of Risk Finance, 9(4): 351-64.

[16]. Ezeoha, A. E. (2011), Firm versus industry financing structures in Nigeria, African Journal of Economic and Management Studies, 2(1): $42-55$

[17]. Ejiofor, P. N. O. (1981), Management in Nigeria: Theories and Issues, Africana Educational Publishers, Onitsha Nigeria.

[18]. Fama, E. F. \& French, K. R. (2002), Testing trade-off and pecking order predictions about dividends and debt, Review of Financial Studies, 15(1): 1-33.

[19]. Fama, E.F. \& Jensen, M. (1983), Separation of ownership and control, The Journal of Law \& Economics, 26: 301-49

[20]. Feldstein, M. (1994), Tax policy and international capital flows, NBER Working Paper No. 4851 (Cambridge, MA: National Bureau of Economic Research).

[21]. Ferri, M. G. \& Jones, W. H. (1979), Determinants of financial structure: A new methodological approach, The Journal of Finance, 34(3): 631-644.

[22]. Gelb, S. (2002), Foreign companies in South Africa: entry, performance and impact, The Edge Institute, South Africa, September.

[23]. Global Development Finance (2007), The globalization of corporate finance in developing countries, The World Bank, 73-107

[24]. Goswami, G. \& Shrikhande, M. M. (2001), Economic exposure and debt financing choice, Journal of Multinational Financial Management, 11(2):39-58

[25]. Harrison, A. E.; Love, I.; \& Mcmillan, M. S. (2004), Global capital flows and financing constraints, Journal of Development Economics, 75:269-301

[26]. Harrison, A. and McMillan, M. (2003), Does direct foreign investment affect domestic firm credit constraints? Journal of International Economics, 61(1): 73-100.

[27]. Hermes N. \& Lensink, R. (2003) 'Foreign direct investment, financial development and economic growth', Journal of Development Studies, 40(1): 142-163

[28]. Hennart, J. (2010), Theories of the multinational Enterprises, In the Oxford Handbook of International Business, pp. 125-145

[29]. Huizinga, H.; Laevenb, L.; \& Nicodeme, G. (2008), Capital structure and international debt shifting, Journal of Financial Economics, 88(1): 80-118

[30]. King, M. (1977), Public Policy and the Corporation, Chapman and Hall Publishers, London.

[31]. Lee, C. \& C. Chang (2009) 'FDI, financial development, and economic growth: international evidence', Journal of Applied Economics, 12(2): 249-271

[32]. Li, K.; Yue, H. \& Zhao, L. (2009), Ownership, institutions, and capital structure: evidence from China, Journal of Comparative Economics, 37(3): 471-490

[33]. Loderer, C. \& Waelchli, U. (2009), Firm Age and Performance, European Corporate Governance Institute, Finance Working Paper No. 230/2009 (http://www.fmpm.ch/docs/12th/papers_2009 web/A4b.pdf) [Accessed July 6, 2016]

[34]. Majumdar, S. K. (2010), Raising corporate debt in India: Has foreign ownership been an asset or a liability? Transnational Corporation: $35-55$

[35]. Ojah, K. \& Pillay, K. (2009), Debt markets and corporate debt structure in an emerging market: The South African example, Economic Modelling, 26(3):1215-1227

[36]. Okafor, F. O. (1983), Investment Decisions: Evaluation of Projects and Securities, Cassell, London.

[37]. Pandey, M. (2004), Capital structure, profitability and market structure: evidence from Malaysia, Asia Pacific Journal of Economics and Business, 8(2): 78-89

[38]. Rajan, G. R. \& Zingales, L. (1995), What do we know about capital structure? Some evidence from international data, Journal of Finance, 50(5): 1421-1460

[39]. Sakai, K.; Uesugi I; \& Watanabe, T. (2010), Firm age and the evolution of borrowing costs: evidence from Japanese small firms, Journal of Banking \& Finance, 34: 1970-1981

[40]. Schoubben, F. \& Van Hulle, C. (2004). The determinants of leverage: differences between quoted and non quoted firms. Trijdschrift voor Economie en Management, 49(4): 589-620.

[41]. Titman, S. \& Wessels, R. (1988), The determinants of capital structure, Journal of Finance, 43(1): 209-243

[42]. United Nations (1973), Multinational Corporations in World Development, Department of Economic and Social Affairs, United Nations, New York. 